\title{
Occult Hepatitis B Virus Infection in Immunocompromised Patients
}

\author{
Ruth Nogueira Cordeiro Moraes Jardim¹, Neiva Sellan Lopes Gonçales ${ }^{1,2}$, Josiane Silveira Felix Pereira ${ }^{1}$, \\ Viviane Cristina Fais ${ }^{1}$ and Fernando Lopes Gonçales Junior ${ }^{1}$ \\ ${ }^{1}$ Study Group of Hepatitis, Infectious Disease, Department of Clinical Medicine, Faculty of Medical Science, State University of Campinas- \\ UNICAMP;갈
}

\begin{abstract}
Occult hepatitis B infection is characterized by hepatitis B virus (HBV) DNA in the serum in the absence of hepatitis B surface antigen (HBsAg). We assessed occult HBV infection prevalence in two groups of immunocompromised patients (maintenance hemodialysis patients and HIV-positive patients) presenting HBsAgnegative and anti-HBc positive serological patterns, co-infected or not by HCV. Thirty-four hemodialysis anti-HIV negative patients, 159 HIV-positive patients and 150 blood donors who were anti-HBc positive (control group) were selected. HBV-DNA was detected by nested-PCR. Occult hepatitis B infection was not observed in the hemodialysis patients group but was found in $5 \%$ of the HIV-patients and in $4 \%$ of the blood donors. Immunosuppression in HIV positive patients was not a determining factor for occult $\mathrm{HBV}$ infection. In addition, no significant relationship between HBV-DNA and HCV co-infection in the HIV-positive patient group was found. A lack of significant associations was also observed between positivity for HBV-DNA and CD4 count, viral load and previous lamivudine treatment in these HIV-positive patients.
\end{abstract}

Key-Words: Occult HBV infection, HBV-DNA, anti-HBc alone, hemodialysis, HIV, immunosupressed patients.

Hepatitis B virus (HBV) infection is a major global health problem. It is estimated that about $350,000,000$ individuals are infected by HBV; infection can induce a wide spectrum of clinical forms, ranging from a healthy carrier state to cirrhosis and hepatocellular carcinoma [1]. HBV infection is usually diagnosed when circulating HBsAg is detected. However, the availability of highly sensitive molecular biology techniques has also allowed the identification of HBV infection in HBsAg-negative individuals, with or without circulating antibodies to HBsAg (anti-HBs) and/ or hepatitis B core antigen (anti-HBc) [2-5].

The failure to detect $\mathrm{HBsAg}$, despite the persistence of the viral DNA, is due in most cases to the strong suppression of viral replication and gene expression that characterizes this "occult” HBV infection [6-9]; although the mechanisms responsible for suppression of $\mathrm{HBV}$ are not well understood.

Occult HBV infection has been studied in selected groups or individuals in which its prevalence is believed to be higher, such as intravenous drug abusers, patients on maintenance hemodialysis, organ transplant patients, patients with chronic HBV infection [10], and patients coinfected with human immunodeficiency virus (HIV) or hepatitis C virus (HCV) [11].

Received on 28 March 2008; revised 14 August 2008.

Address for correspondence: Dr. Fernando Lopes Gonçales Junior. Grupo de Estudos das Hepatites, Disciplina de Moléstias Infecciosas, Departamento de Clínica Médica, Faculdade de Ciências Médicas, UNICAMP. Rua Tessália Vieira de Camargo, 126. Cidade universitária, Campinas, São Paulo, Brazil. Zip code: 13083-970. Telephone/ fax number: 55-19- 3521-7727. Email: flgj@uol.com.br. Research supported by Fundo de Apoio ao Ensino, Pesquisa e Extensão (FAEPEX) UNICAMP.

The Brazilian Journal of Infectious Diseases 2008;12(4):300-305. (C) 2008 by The Brazilian Journal of Infectious Diseases and Contexto Publishing. All rights reserved.
However the magnitude and pattern of occult HBV infection among immunocompromised patients, such as hemodialysis and HIV patients, is not well established yet. In maintenance hemodialysis patients, the risk of acquiring HBV and HCV infection is high, due to the dialysis process $[12,13]$; consequently, the probability of patients becoming chronic carriers is higher than for the general population. In HIV-positive patients, co-infection with HBV and HCV is common due to the common route of transmission of these diseases. In patients coinfected with HBV and HIV, it has been suggested that HIV interferes with the natural history of HBV infection by enhancing HBV replication [14] and that immunossupression associated with HIV infection allows reinfection or reactivation of a past HBV infection $[15,16]$.

We examined occult HBV infection prevalence in two groups of immunocompromised patients (maintenance hemodialysis patients and HIV-positive patients), who present HBsAg-negative and anti-HBc positive serological patterns, co-infected or not by HCV. Possible correlations were investigated between the prevalence of HBV DNA, viral loads, CD4 levels and previous lamivudine administration in the HIV group.

\section{Material and Methods}

The study was performed between 2002 and 2005 in the Laboratory of the Hepatitis Study Group of the Infectious Diseases Department, School of Medical Sciences, State University of Campinas (UNICAMP), after approval by the Institutional Ethics Committee. All adult hemodialysis patients originated from two dialysis centers in São Jõao da Boa Vista, São Paulo State, Brazil. HIV-positive patients were selected during their clinical follow-up at the Clinical Hospital of the University of Campinas; only those presenting a serological pattern of HBsAg negative and anti-HBc positive, co-infected or not by HCV, were included. 
Table 1. Prevalence of occult HBV infection (HBV DNA positivity) in the groups studied.

\begin{tabular}{|c|c|c|c|c|}
\hline Groups & No & HBV DNA positive (\%) & HBV DNA negative (\%) & pvalue \\
\hline GI - Hemodialysis Patients & 34 & - & (100) & \\
\hline Anti-HBc+/Anti-HBs-/Anti-HCV- & 8 & - & (100) & NS \\
\hline Anti-HBc+/Anti-HBs+-/Anti-HCV- & 19 & - & (100) & NS \\
\hline Anti-HBc+/Anti-HBs-/Anti-HCV+ & 1 & - & (100) & NS \\
\hline Anti-HBc+/Anti-HBs+/Anti-HCV+ & 6 & - & (100) & NS \\
\hline GII - HIV-positive patients & 159 & $(5.0)$ & (95.0) & \\
\hline Anti-HBc+/Anti-HBs-/Anti-HCV- & 15 & (6.7) & (93.3) & NS \\
\hline Anti-HBc+/Anti-HBs+-/Anti-HCV- & 56 & (7.2) & $(92.8)$ & NS \\
\hline Anti-HBc+/Anti-HBs-/Anti-HCV+ & 30 & (3.3) & (96.7) & NS \\
\hline Anti-HBc+/Anti-HBs+/Anti-HCV+ & 58 & (3.5) & (96.5) & NS \\
\hline GIII - Blood donors & 150 & $(4.0)$ & $(96.0)$ & \\
\hline Anti-HBc+/Anti-HBs-/Anti-HCV- & 100 & $(6.0)$ & $(94.0)$ & NS \\
\hline Anti-HBc+/Anti-HBs+-/Anti-HCV- & 50 & - & (100) & NS \\
\hline
\end{tabular}

A total of 343 samples were analyzed. The samples were distributed into three groups:

\section{Group I}

Thirty-four adult hemodialysis patients who were HBsAg negative, anti-HBc postive and anti-HIV negative (18 [53\%] males and 16 [47\%] females; mean age $53.7 \pm 10.10$ years; range 29-76 years) were included. Seven (20.6\%) of them were also co-infected with HCV (Table 1).

Group II

One hundred and fifty nine HIV-positive patients coinfected by HBV (HBsAg negative and anti-HBc positive) were selected (129 [81\%] male and 30 [19\%] female; mean age $39.9 \pm 8.31$ years; range $22-67$ years). Eighty-eight (55.3\%) of them were also co-infected by HCV (Table1).

\section{Group III}

One hundred fifty volunteer blood donors with HBsAg negative and anti-HBc positive serological patterns (102 [68\%] males and 42 [32\%] females; mean age 41.810 .78 years; range $18-64$ years) were studied. This group was being analyzed for another study and was included in our study as a control group. All of these individuals were negative for syphilis, anti-HCV, anti-HIV and anti-HTLV I/II (Table 1).

\section{Serology}

Testing for HBsAg was performed with a thirdgeneration monoclonal enzyme immunoassay (Abbott/ Murex, Dartford, England). Anti-HBc was screened using a competitive enzyme immunoassay (Abbott/Murex, Dartford, England). Anti-HBs was tested using an enzyme immunoassay (ETI-AB AUK-3, Diasorin, Itály). Antibodies to HCV were detected with a fourth-generation enzyme immunoassay (Abbott/Murex Dartford, England). For detection of antibodies to HIV 1/2, two different assays were utilized, a third-generation assay (Abbott/Murex Dartford, England) and an antigen/antibody combo assay
(Abbott/Murex, Dartford, England), confirmed with a Western Blot. All samples were tested according to the manufacturer's instructions. The samples were considered positive when absorbance was greater than the cutoff and presented the same result in duplicate.

The samples that tested HBV-DNA positive were retested for HBsAg, in a fully automated quantitative chemiluminescent microparticle immunoassay (CMIA) Architect HBsAg (Abbott Laboratories, Sligo, Ireland) that is able to detect the most frequent mutants of the HBV S region, in order to confirm the status of occult HBV infection. This Architect HBsAg Qt assay was used according to the manufacturer's protocol. The resulting chemiluminescent reaction was measured in relative light units (RLUs). A direct relationship exists between the amount of HBsAg in the sample and the number of RLUs. Architect HBsAg Qt is capable of measuring a wide range of from 0.05 to $250 \mathrm{IU} / \mathrm{mL}$.

\section{HVB-DNA}

Serum samples were stored at $-20^{\circ} \mathrm{C}$ and thawed immediately before use. For detection of HBV DNA, nested in house PCR was used as described by Kaneko et al. [17]. The 5'-3' nucleotide (nt) sequences of the primers were as follows: outer primers HBV1763 (GCT TTG GGG CAT GGA CAT TGA CCC GTA TAA)' and HBV2032R (CTG ACT ACT AAT TCC CTG GAT GCT GGG TCT-3'); inner primers HBV 1778E (GAC GAATTC CATTGA CCC GTATAAAGAATT)' and HBV 2017RB (ATG GGA TCC CTG GAT GCT GGG TCT TCC AAA-3'). After both reactions, a 270 nucleotide fragment was obtained and detected by agarose gel electrophoresis. To prevent carryover contamination during PCR, each step of the procedure was performed in a separate room with dedicated equipment and directional flow from the beginning of the procedure to the end. Negative controls consisting of water were also included in each extraction run, and an extra negative control consisting of water was included as a last sample in each PCR run. Serial dilutions were made in an HBsAg low-titer performance 
Table 2. Epidemiological, clinical and laboratorial findings in HIV-positive patients and blood donors.

\begin{tabular}{|c|c|c|c|c|}
\hline \multirow{2}{*}{$\frac{\text { Clinical features }}{\text { HIV-positive patients }}$} & \multirow{2}{*}{$\begin{array}{l}\text { No } \\
159\end{array}$} & \multirow{2}{*}{$\frac{\text { HBV-DNApositive (\%) }}{8(5.0)}$} & \multicolumn{2}{|c|}{ HBV DNA negative (\%) } \\
\hline & & & 151 & $(95.0)$ \\
\hline \multicolumn{5}{|l|}{ Source of infection } \\
\hline Intravenous drug abusers & 46 & $3(6.5)$ & 43 & $(93.5)$ \\
\hline Sexual & 51 & $4(7.8)$ & 47 & $(92.2)$ \\
\hline Sexual/Parenteral & 17 & $1(5.8)$ & 16 & $(94.2)$ \\
\hline Unknown & 45 & $-\quad-$ & 44 & (100) \\
\hline \multicolumn{5}{|l|}{ CD4+ cell count (cells/mL) } \\
\hline$<200$ & 37 & $1(2.7)$ & 36 & (97.3) \\
\hline $200-350$ & 32 & 1 (3.1) & 31 & (96.9) \\
\hline$>350$ & 90 & $6(6.7)$ & 84 & (93.3) \\
\hline \multicolumn{5}{|c|}{ Plasma HIV-RNA load (copies/mL) } \\
\hline$<10^{4}$ & 113 & $5(4.4)$ & 98 & $(94.6)$ \\
\hline $10^{4}$ to $10^{5}$ & 25 & $1(4.0)$ & 24 & $(96.0)$ \\
\hline$>10^{5}$ & 21 & $2(9.5)$ & 19 & $(90.5)$ \\
\hline \multicolumn{5}{|l|}{ HAART treatment } \\
\hline Yes & 130 & $7(5.4)$ & 123 & $(94.6)$ \\
\hline No & 29 & 1 (3.5) & 28 & (96.5) \\
\hline \multicolumn{5}{|l|}{ Lamivudine } \\
\hline Yes & 80 & $4(5.0)$ & 76 & $(95.0)$ \\
\hline No & 50 & $4(8.0)$ & 46 & $(92.0)$ \\
\hline Blood donors & 150 & $6(4.0)$ & 94 & $(94.0)$ \\
\hline \multicolumn{5}{|l|}{ Risk Factors } \\
\hline Sexual & 29 & $2(6.8)$ & 27 & $(93.2)$ \\
\hline Parenteral & 35 & $1(2.9)$ & 34 & $(97.1)$ \\
\hline Parenteral/Sexual & 17 & - (100) & 17 & $(100)$ \\
\hline Unknown & 69 & $4(5.8)$ & 65 & (94.2) \\
\hline
\end{tabular}

Table 3. Clinical aspects, serological data, plasma HIV-RNA load, CD4+ count and lamivudine as part of HAART therapy in HIV patients with occult HBV infection.

\begin{tabular}{ccccccccccc}
\hline Patients & $\begin{array}{c}\text { Date of } \\
\text { diagnosis }\end{array}$ & Sex & $\begin{array}{c}\text { Age in } \\
\text { years }\end{array}$ & $\begin{array}{c}\text { Risk } \\
\text { factor }\end{array}$ & HIV status & HIV viral & $\begin{array}{c}\text { CD4+ } \\
\text { load }\end{array}$ & Lam & $\begin{array}{c}\text { Anti-HBs } \\
\text { (cells/mL) }\end{array}$ & $\begin{array}{c}\text { Anti- } \\
\text { HCV }\end{array}$ \\
\hline 1 & 1994 & M & 44 & Bisexual & AIDS B3 & 2,500 & 521 & no & no & no \\
2 & 1993 & M & 36 & IDA & AIDS & 750 & 418 & no & yes & yes \\
3 & 1995 & M & 38 & IDA & AIDS & 170,000 & 280 & yes & yes & yes \\
4 & 1995 & M & 33 & IDA & AIDS C3 & 22,000 & 154 & no & no & yes \\
5 & 1992 & M & 62 & Homo & AIDS C3 & $<$ LD & 461 & yes & yes & no \\
6 & 1997 & F & 34 & IDA & AIDS & 110,000 & 551 & yes & yes & no \\
7 & 1997 & F & 47 & HIV partner & AIDS & $<$ LD & 409 & yes & yes & no \\
8 & 1998 & M & 43 & IDA/Homo & AIDS A2 & $<$ LD & 501 & no & yes & no \\
\hline
\end{tabular}

IDA=intravenous drug abusers; IDA/Homo=intravenous drug user and homosexual; Homo=homosexual; Lam=lamivudine; LD=limit of detection.

panel (PHA 105, Boston Biomedica Inc, Boston, Mass.), which made it possible to establish a limit of detection by nested PCR of $10^{2}$ copies $/ \mathrm{mL}$.

\section{Statistical Analysis}

Statistical comparison of distribution was carried out using either the chi-square or the Fisher exact tests, as applicable. For comparison of means and variances, other tests were used (Student t, Kruskal-Wallis, and Mann-Whitney tests). The level of significance was set at $\mathrm{p}<0.05$.

\section{Results}

Among 34 maintenance hemodialysis patients (Group I), 27 (79.4\%) were anti-HBc positive and anti-HCV negative; among these, eight (29.6\%) were anti-HBc alone and seven (20.6\%) were anti-HBc plus anti-HCV positive. HBV-DNA was not detected in any serum from the patients in this group (Table 1).

Among the 159 HIV-positive patients (Group II), 71 (44.6\%) were anti-HBc positive and anti-HCV negative, 15 (21\%) of them were anti-HBc alone, while the other 88 (55\%) patients in this group were co-infected with $\mathrm{HCV}$; anti-HBc alone was 
found in 30 (34\%) of patients of this group. HBV-DNA was detected in eight (5\%) of the patients in this group. Among the HIV-positive patients that were HCV-negative, HBV DNA was found in 5/71 (7.0\%); one (6.7\%) presented anti-HBc alone and four (7.2\%) were anti-HBc and anti-HBs positive. HVB DNA was also observed in 3/88 (3.4\%) HIV-positive patients co-infected with HCV, one (3.4\%) was anti-HBC alone and two (3.5\%) had anti-HBc and anti-HBs positive markers. No significant difference in the presence of HBV-DNA was observed in HIV-positive patients co-infected or not with HCV; similarly, no significant difference was observed in the presence or absence of anti-HBs (Table1).

Among the 150 blood donors (Group III), HBV DNA was detected in six (4\%). No HBV-DNA was found in blood donors that were anti-HBs positive only, among those that presented anti-HBc alone. The prevalence of HBV DNA in Groups II and III was similar (5 and 4\% respectively); in Group II, HBV-DNA was also found in HIV-positive patients that were anti-HBs positive (Table 1).

Among the 159 patients infected with HIV-1, 51 (32\%) had as a risk factor for acquired HIV and HBV unsafe sexual practices, 46 (29\%) were intravenous drug abusers, 17 (10.7\%) presented two risk factors (sexual and parenteral), and in 45 (28.3\%) it was not possible to determine the risk factor. Among 150 blood donors, 35(23.4\%) related parenteral exposure, 29(19.3\%) reported unsafe sexual practices, 17 (11.3\%) had both parenteral and sexual exposure, and in 69 (46\%) no known risk factors were reported. The finding of HBV DNA was not significantly associated with risk factors in the two groups ( $>0.05$, Table 2 ).

Among the other HIV-positive patients, 90 (57\%) presented a TCD4+ count of more than 350 cells/mL, 113 (71\%) presented a viral load of less than 10,000 copies/mL, 130 (82\%) were under antiretroviral treatment, and 80 (61\%) of the patients received lamivudine as part of a HAART scheme. HBV-DNA was detected in six (6.7\%) of the HIV-positive patients, with CD4+ counts above 350 cells $/ \mathrm{mL}$, five (4.4\%) had a viral load $<10,000$, in four (5\%) HIV-positive patients who were being treated with lamivudine, and in four (8\%) of the patients who had not used lamivudine The frequency of occult HBV infection was not significantly different, with variations in TCD4+ count, HIV viral load or lamivudine treatment ( $\mathrm{p}>0.05$, Table 2 ).

Table 3 shows the clinical and serological features, as well as the TCD4+ counts and HIV viral load of the eight patients who tested positive for HBV-DNA. All patients who were HBVDNA positive were classified as having AIDS. Six (75\%) of them were anti-HBs positive; only one was anti-HBc alone. These patients were in follow-up for an average of 10 years since the initial anti-HIV serology-confirmed diagnosis. Among these patients, six (75\%) had TCD4+ counts above 350 cells/mL and three (37.5\%) presented a viral load below the detection limit.

\section{Discussion}

The relationship between occult HBV infection and liver disease is still unclear. Occult HBV infection has received much attention recently, since it has been detected in patients with hepatocarcinoma [18], in blood donors and transfused patients $[19,20]$, and in patients infected with hepatitis $C$ virus [21-23]. In chronic HCV patients on hemodialysis, the prevalence of occult HBV infection is not yet well known $[22,24]$. Some studies have demonstrated that HIV infection modifies the natural history of HBV and HCV infections [25], increasing the progression to chronic disease. Among immunocompromised patients, HBV-DNA can be detected in $10 \%$ of HBsAg negative/anti-HBc positive patients. Reactivation of HBV is rare [10]; reactivation of HBV has recently been described in an HIV-positive patient who was anti-HBc alone [26].

The main characteristic of occult HBV infection is HBV DNA at low levels in serum and hepatic tissue [27]. Due to the high sensitivity (100 copies/mL) of the in house PCR used in our study, we were able to identify HBV DNA in the serum of HBV infected patients even when they had few copies. Commercial disposable tests only detect more than 1,000 copies/mL.

The data recorded from hemodialysed patients in our study were similar to those encountered in another study made in Italy [12], in which no occult infection was found in 213 patients from five different centers.

Clearance of HBV-DNA is expected to occur following loss of HBsAg and seroconversion to anti-HBs; anti-HBs is considered the classical marker of past-resolved infection. In some cases, however, HBV DNA has been detected in antiHBs-positive sera [5] and even in individuals without HBV serological markers [28]. Persistence of HBV DNA after seroconversion to anti-HBs has been documented more frequently in patients with chronic liver disease than in asymptomatic carriers. HBV DNA was found in $10 \%$ of patients with anti-HBc alone and in 20\% of patients with anti-HBs and anti-HBc. These results are in agreement with previous findings, which demonstrated that HBV DNA detection is elevated in HBsAg-negative, HIV-infected patients [29].

A number of explanations for the persistence of HBV DNA in HBS-negative samples have been proposed, including HBV DNA in low copy numbers [27], genetic variations of the $S$ gene $[30,31]$, and immune complexes in which HBsAg is hidden [32].

A key question to understanding the role of occult $\mathrm{HBV}$ infection is whether small amounts of HBV will lead to progressive liver disease. Systemic detection of HBV DNA levels in HIV-positive individuals, with and without HBsAg, as well as further study of the association between HBV DNA and markers of liver function, should help to answer this question.

Suppression of HBV DNA by lamivudine has been demonstrated in studies of patients chronically infected with HBV [33-35]. In cases of co-infected HBV-HIV patients who received lamivudine as part of their antiretroviral treatment, loss of HBV DNA after one year of treatment was observed in $96.3 \%$ of patients when assessed by molecular hybridization

www.bjid.com.br 
and $88.5 \%$ of patients assessed by PCR [36]. However, trials on lamivudine treatment have been performed with HBsAgpositive patients alone, co-infected with HIV or not; the effects of lamivudine were analyzed at various intervals after the beginning of therapy $[37,38]$.

The loss of HBV DNA due to lamivudine treatment is usually accompanied by significant histological and biochemical improvement [39]. The main limitation for the use of lamivudine is the selection of resistant mutations that affect the YMDD motif of HBV polymerase and that may arise during therapy. Such mutations have also been reported in studies of patients co-infected with HIV and HBV $[37,40]$.

In our cross-sectional study, no significant differences in the prevalence of HBV DNA or of HBV viral load were observed between patients under lamivudine treatment and those not receiving lamivudine. Indeed, it is known that increased duration of lamivudine treatment is associated with an increasing number of resistance mutations. In a recent study conducted with HIV-HBV co-infected patients, it was observed that the rate of resistance mutations increased from $25 \%$ after one year of treatment to $52 \%$ after two years [38]. The efficacy of lamivudine treatment and the rate of resistance mutations in patients with occult HBV infection have not yet been investigated. To determine the effect of lamivudine treatment on HBsAg-negative patients, the rates and pattern of lamivudine-resistant mutations should be investigated in this particular group of HIV-HBV infected individuals.

In conclusion, the finding of HBV DNA in individuals without serological markers for $\mathrm{HBV}$ reinforces the importance of a revised definition of hepatitis $B$, which is currently based on HBsAg.

\section{Acknowledgments}

We thank Nicola Conran for her helpful English review.

\section{References}

1. Lee M.Y. Hepatitis B virus infection. N Engl J Med 1997;24:1733-45.

2. Brechot C., Hadchouel M., Scotto J., et al. State of hepatitis B virus DNA in hepatocytes of patients with hepatitis B surface antigen positive and negative liver disease. Proc.Natl Acad Sci USA 1981;78:3906-10.

3. Thiers V., Nakajima E., Kremsdorf D., et al. A transmission of hepatitis B from hepatitis B seronegative subjects. Lancet 1988; 2 :1273-6.

4. Wang J.T., Wang T.H., Sheu J.C., et al. Detection of hepatitis B virus DNA by polymerase chain reaction in plasma of volunteer blood donors negative for hepatitis B surface antigen. J Infect Dis 1991;163:397-9.

5. Loriot M.A., Marcellin P., Bismuth E., et al. Demonstration of hepatitis B virus DNA polymerase chain reaction in the serum and the liver after spontaneous or therapeutically induced $\mathrm{HBeAg}$ to anti-HBe or HBsAg to anti-HBs seroconversion in patients with chronic hepatitis B. Hepatology 1992;15:32-36.

6. Liang T.J., Baruch Y., Ben-Porath E., et al. Hepatitis B virus infection in patients with idiopathic liver disease. Hepatology 1991;13:1044-51.

7. Medrano F.J., Sanchez-Quijano A., Pineda J., Lissen E. Isolated anti-HBc and hepatitis B virus occult infection. Vox sang 1991;61:140.
8. Sanchez-Quijano A., Jauregui J.I., Leal M., et al. Hepatitis B virus occult infection in subjects with persistent isolated anti-HBc reactivity. J Hepatol 1993;17:288-93.

9. Villa E., Grottola A., Buttafoco P., et al. Evidence for hepatitis B virus infection in patients with chronic hepatitis $\mathrm{C}$ with and without serological markers of hepatitis B. Dig Dis Sci 1995;40:8-13.

10. Grob P., Jilg W., Bornhak H., et al. serological pattern "Anti-HBc Alone": Report on a workshop. J Med Virol 2000;62:450-5.

11. Gonçales Junior F.L., Pereira J.S.F., Silva C., et al. Hepatitis B virus DNA in sera of blood donors and of patients infected with hepatitis $\mathrm{C}$ virus and human immunodeficiency virus. Clin Diagn Lab Immunol 2003;10718-20.

12. Fabrizi F., Messa P.G., Lunghi G., et al. Occult hepatitis B virus in dialysis patients: a multicentre survey. Aliment Pharmacol Ther 2005;21:1341-7.

13. Burdick R.A., Bragg-Gresha M.J.L., Woods J.D., et al. Patterns of hepatitis B prevalence and seroconversion in hemodialysis units from three continents: the DOPPS. Kidney Int 2003;63:2222-9.

14. Pastore G., Santantonio T., Monno L., et al. Effects of HIV superinfection on HBV replication in a chronic HbsAg carrier with liver disease. J Hepatol 1998;2:164-8.

15. Gilson R.J., Tedder R.S., Weller I.V. Hepatitis B: reactivation or reinfection associated with HIV-1 infection.Lancet ii:1330.

16. Hino K., Basumi A.A., Ireland J., et al. Reappearance of hepatitis B surface antigen in immunocompromised individuals:reinfection or reactivation? Dig Dis Sci 2002;47:415-8.

17. Kaneko S., Feinstone S.M., Miller R.H. Rapid and sensitive method for the detection of serum hepatitis B virus DNA using the polymerase chain reaction technique. J Clin Microbiol 1989;27:1930-3.

18. Paterlini P., Gerken G., Nakajima E., et al. Polymerase chain reaction to detect hepatitis $B$ virus DNA and RNA sequences in primary liver cancers from patients negative for hepatitis B surface antigen. N Eng J Med 1990;323:80-5.

19. Baginski I., Chemin I., Hantz O., et al. Transmission of serologically silent hepatitis B virus along with hepatitis $C$ virus in two cases of posttransfusion hepatitis. Transfusion 1992;32:215-20.

20. Pereira J.S., Gonçales N.S., Silva C., et al. HBV vaccination of HCV-infected patients with occult HBV infection and anti-HBcpositive blood donors. Braz J Med Biol Res 2006;39:525-3.

21. Fukuda R., Ishimura N., Niigaki M., et al. Serologically silent hepatitis $B$ virus coinfection in patients with hepatitis $C$ virusassociated chronic liver disease: clinical and virological significance. J Med Virol 1999;58:201-7.

22. Cacciola I., Pollicino T., Squadrito G., et al. Occult hepatitis B virus infection in patients with chronic hepatitis $\mathrm{C}$ liver disease. N Engl J Med 1999;341:22-6.

23. Silva C., Gonçales N.S., Pereira J.S., et al. The influence of occult infection with hepatitis B virus on liver histology and response to interferon treatment in chronic hepatitis C patients. Braz $\mathrm{J}$ Infect Dis 2004;8:431-9.

24. Besiisik F., Karaca C., Akyuz F., et al. Occult HBV infection and YMDD variants in hemodialysis patients with chronic HCV infection. J Hepatol 2003;38:506-10.

25. Puoti M., Torti C., Bruno R., et al. Natural history of chronic hepatitis B in co-infected patients. J Hepatol 2006;44:565-70.

26. Chamorro A.J., Casado J.L., Bellido D., Moreno S. Reactivation of hepatitis B in an HIV-infected patient with antibodies against hepatitis B core antigen as the only serological marker. Eur J Clin Microbiol Infect Dis 2005;24(7):492-4.

27. Brechot C., Thiers V., Kremsdorf D., et al. Persistent hepatitis B virus infection in subjects without hepatitis B surface antigen: clinically significant or purely "occult”? Hepatology 2001;34(1):194-203.

28. Luo K.X., Zhou R., Liang Z.S., Jiang S.B. Hepatitis B virus DNA in sera of virus carriers positive exclusively for antibodies to hepatitis B core antigen. J Med Virol. 2002;35:59-9. 
29. Hofer M., Joller-Jemelka H.I., Grob P.J., et al. Frequent chronic hepatitis B virus infection in HIV-infected patients positive for antibody to hepatitis B core antigen only. Swiss HIV Cohort Study.Eur J Clin Microbiol Infect Dis 1998; $17: 6-13$.

30. Carman W.F. The clinical significance of surface antigen variants of hepatitis B virus. J Viral Hepat 1997;1:11-20.

31. Zuckerman J.N., Zuckerman A.J. Current topics in hepatitis B. J Infect 2000;41:130-6.

32. Ackerman Z., Wands J.R., Gazitt Y., et al. Enhancement of HBsAg detection in serum of patients with chronic liver disease following removal of circulating immune complexes. J Hepatol 1994;40:398-404.

33. Dienstag J.L., Perrillo R.P., Schiff E.R., et al. A preliminary trial of lamivudine for chronic hepatitis B infection. N Engl J Med 333:1657-61.

34. Dore G.J., Cooper D.A., Barrett C., et al. Dual efficacy of lamivudine treatment in human immunodeficiency virus/hepatitis B viruscoinfected persons in a randomized, controlled study (CAESAR). The CAESAR Coordinating Committee. J Infect Dis 1999;180:607-13.
35. Nevens F., Main J., Honkoop P., et al. Lamivudine therapy for chronic hepatitis B: a six-month randomized dose-ranging study. Gastroenterology 1997;113:1258-63.

36. Benhamou Y., Katlama C., Lunel F., et al. Effects of lamivudine on replication of hepatitis B virus in HIV-infected men. Ann Intern Med 1996;125:705-12.

37. Hoff J., Bani-Sadr F., Gassin M., Raffi F. Evaluation of chronic hepatitis B virus (HBV) infection in coinfected patients receiving lamivudine as a component of anti-human immunodeficiency virus regimens. Clin Infect Dis 2001;32:963-9.

38. Wolters L.M., Hansen B.E., Niesters H.G., de Man R.A. Viral dynamics in chronic hepatitis B patients treated with lamivudine, lamivudine-famciclovir or lamivudine-ganciclovir. Eur J Gastroenterol Hepatol 2002;14:1007-11.

39. Honkoop P., de Man R.A., Zondervan P.E., Schalm S.W. Histological improvement in patients with chronic hepatitis B virus infection treated with lamivudine. Liver 1997;17:103-7.

40. Thibault V., Behamou Y., Seguret C., et al. Hepatitis B virus (HBV) mutations associated with resistance to lamivudine in patients coinfected with HBV and human immunodeficiency virus. J Clin Microbiol 1999;37:3013-6. 